\author{
SERIES 'AIRWAY MUCUS' \\ Edited by P.K. Jeffery \\ Number 8 in this Series
}

\title{
Current opinion of muco-active drug research: strategies and problems
}

\author{
T. Miyata, H. Kai, Y. Isohama, K. Takahama
}

\begin{abstract}
Current opinion of muco-active drug research: strategies and problems. T. Miyata, $H$ Kai, Y. Isohama, K. Takahama. CERS Journals Ltd 1997.

ABSTRACT: In general, mucoactive drugs are classified into several groups. However, since many drugs have overlapping effects, it is difficult to classify the drugs into groups based on their major actions. It has been reported that many mucoactive drugs have antioxidant effects. It is reasonable to suggest that an antiinflammatory property is crucial to demonstrate effectiveness in a clinical context. From this point of view, we have evaluated several mucoactive drugs over two decades. Of these, we will consider the following drugs with anti-inflammatory properties: sodium aceneuramate; glucocorticoids; traditional Chinese medicines; and new cysteine derivatives. On the basis of these findings, we believe that the efforts to seek for compatible actions between glucocorticoids and oriental medicines may provide new opportunities for development of ideal mucoactive drugs with specified actions, i.e. suppression of gene expression.
\end{abstract} Eur Respir J 1998; 11: 480-491.
Dept of Pharmacological Sciences, Faculty of Pharmaceutical Sciences, Kumamoto University, 5-1 Oe-honmachi, Kumamoto 862, Japan.

Correspondence: T. Miyata, Dept of Pharmacological Sciences, Faculty of Pharmaceutical Sciences, Kumamoto University, 5-1 Oe-honmachi, Kumamoto 862, Japan Fax: 81963627795

Keywords: Airway secretion, Chinese medicine, cysteine derivatives, glucocorticoid, mucoactive drug, mucus

Received: February 241997

Accepted after revision February 261997
Disturbance of the normal mucociliary clearance due to hyperproduction of mucus and modification of its physicochemical characteristics is a common finding in airway diseases. Drugs that affect airway secretion have been proposed and used to cleanse the respiratory tract for many centuries and in many countries. On the basis of the mechanism of their actions, the mucoactive drugs were classified into several groups [1]. Some mucoactive drugs have direct effects on the production or composition of airway secretions, resulting in increased effectiveness of mucociliary clearance. The other mucoactive drugs do not have a specific action on mucus, but have beneficial effects on airway structure and function, which lead to correction of pathophysiological mechanisms that result in abnormal secretions.

However, since many drugs have overlapping effects, it is difficult to classify these drugs into groups based on their major actions. For example, it is well known that ambroxol stimulates the formation and release of pulmonary surfactant by alveolar type II cells [2]. However, recent reports indicate that ambroxol as well as $\mathrm{N}$-acetyl-L-cysteine and carboxymethylcysteine could sufficiently enhance the antioxidant defense mechanisms in lung tissues and could act as lung lipid antioxidants [3-7]. In addition, ambroxol inhibited the chemotactic response and spontaneous migration of human poly- morphonuclear leucocytes (PMNLs) [8-10], and attenuated the production of interleukin-1 and tumor necrosis factor by human mononuclear cells [11]. In in vivo studies, ambroxol diminished the bleomycin-induced lung injury in rats [12], and decreased mortality after administration of paraquat, a herbicide that generates reactive oxygen species [13]. It can be concluded that ambroxol has an anti-inflammatory action. Taken together with previous findings of mucoactive drugs, it seems to us that the antioxidant effect is a common property in mucoactive drugs and that it is a crucial action to exert their effects against airway diseases.

In the light of this idea, we must use specific experimental models to simulate pharmacological events in airway inflammation. Nowadays, the development of new techniques has made it possible to identify and measure the mucus components, to measure the rheological parameters more accurately, and to evaluate mucociliary clearance precisely in animals and humans. Therefore, with modifications of methods, we have evaluated mucoactive drugs from various points of view in order to reflect actions in inflammatory states over two decades. Here, we introduce the methods we have used to study many of the parameters involved in airway clearance, and we describe some of the mucoactive drugs that we have studied recently.

Previous articles in this series: No. 1: P.K. Jeffery, D. Li. Airway mucosa: secretory cells, mucus and mucin genes. Eur Respir J 1997; 10: 1655-1662. No. 2: W.D. Kim. Lung mucus: a clinician's view. Eur Respir J 1997; 10: 1914-1917. No. 3: L.D. Martin, L.G. Rochelle, B.M. Fischer, T.M. Krunkosky, K.B. Adler. Airway epitlelium as an effector of inflammation: molecular regulation of secondary mediators. Eur Respir $J$ 1997; 10: 2139-2146. No. 4: R. Wu, Y.H. Zhao, M.M.J. Chang. Growth and differentiation of conducting airway epithelial cells in culture. Eur Respir J 1997; 10: 2398-2463. No. 5: K.C. Kim, K. McCracken, C.Y. Shin, M. Jo, C.J. Lee, K.H. Ho. Airway goblet cell mucin: its structure and regulation of secretion. Eur Respir J 1997; 10: 2644-2649. No. 6: J.H. Widdicombe, S.J. Bastacky, D.X-Y. Wu, C.Y. Lee. Regulation of depth and composition of airway surface liquid. Eur Respir J 1997; 10: 2892-2897. No. 7: M. King. Experimental models for studying mucociliary clearance. Eur Respir J 1998; 11: 222-228. 
Table 1. - Sugar components of airway secretions in normal and bronchitic rabbits

\begin{tabular}{lccccc}
\hline & \multicolumn{5}{c}{ Components } \\
\cline { 2 - 6 } Animals & Fucose & Galactose & GalNAc ${ }^{-1}$ protein & GlcNAc & NANA \\
\hline Normal & $13.0 \pm 2.4$ & $45.4 \pm 2.9$ & $68.3 \pm 3.7$ & $41.8 \pm 1.5$ & $18.6 \pm 1.6$ \\
Bronchitic & $30.9 \pm 7.6$ & $122.0 \pm 31.0$ & $259.3 \pm 74.9$ & $83.8 \pm 10.2$ & $34.5 \pm 2.5$ \\
\hline
\end{tabular}

GalNAc: N-acetylgalactosamine; GlcNAc: N-acetylglucosamine; NANA: N-acetylneuraminic acid.

\section{Screening systems for mucoactive drugs}

In vivo screening systems for airway secretion in inflammation

There are several experimental models of airway inflammation. Amongst these, we used a sulphur dioxide $\left(\mathrm{SO}_{2}\right)$ exposed model as an in vivo screening system for airway secretion in inflammation, because $\mathrm{SO}_{2}$ mainly causes airway epithelial damage similar to features of bronchitis. There are two convenient methods to study airway secretion: the Perry and Boyd method [14, 15], and the bronchoalveolar lavage method.

The Perry and Boyd method has been used extensively to study the effects of sympathetic or parasympathetic agents and the effects of many kinds of mucoactive drugs. In our previous studies, the mucous production of rabbits with subacute bronchitis induced by a long-term exposure (5 weeks to 3 months) to $\mathrm{SO}_{2}$ (50-300 parts per million (ppm)) has been determined with this method. We determined sugar, protein and phospholipid contents in airway secretions from normal and bronchitic rabbits and evaluated the effects of various mucoactive drugs on airway secretion [16-21]. The majority of sugars in mucins are composed of fucose, galactose, $\mathrm{N}$-acetylgalactosamine, $\mathrm{N}$-acetylglucosamine and $\mathrm{N}$-acetylneuraminic acid. As shown in table 1, we found that the sugars were increased in airway secretions of rabbits exposed to $\mathrm{SO}_{2}$. The finding that there was a large increase in galactose and $\mathrm{N}$-acetylglucosamine is similar to that observed in the sputum of bronchitic patients. The finding suggests that airway secretions from rabbits exposed to $\mathrm{SO}_{2}$ are composed of long chains of sugars in mucins, resulting in secretions with a viscous nature, similar to the sputa of bronchitic patients. The reason is that these two sugars are major components of the elongated sugars in mucins. Figure 1 shows the basis of the sugar structure of mucin.

Bronchoalveolar lavage methods were also employed to study airway secretions. The advantage of this method

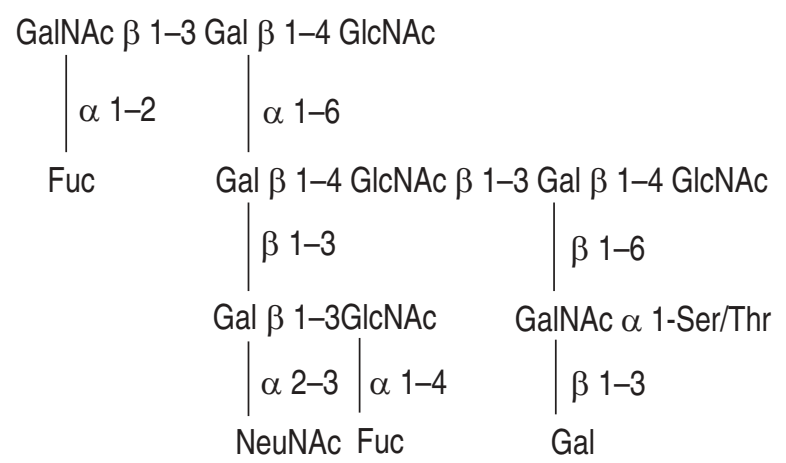

Fig. 1. - Schematic representation of the structure of O-linked carbohydrate. GalNAc: N-acetylgalactosamine; Gal: galactose; GlcNAc: Nacetylglucosamine; Fuc: fucose; NeuNAc: $\mathrm{N}$-acetylneuraminic acid; Ser/Thr: serine or threonine. is that many components can be examined quantitatively and qualitatively. For example, we examined the influence of long-term exposure to $\mathrm{SO}_{2}$ on the pulmonary surfactant by this method [21]. Recently, in order to investigate mucin production in pathological states, we made monoclonal antibodies (4H6, 2D11) against the mucins from bronchoalveolar lavages of hamsters with bronchitis caused by $\mathrm{SO}_{2}$ exposure [22]. In the immunohistochemical studies, the antibodies recognized the mucins secreted into the lumen, but not those stored in goblet cells or submucosal gland mucous cells (fig. 2). The enzyme-linked immunosorbent assay (ELISA) method has shown that the antibodies react with some mucins from hamster intestine and swine stomach, and bronchoalveolar lavages of rats, guinea-pigs, dogs and humans. However, the antibodies did not recognize bovine submaxillary gland mucins or proteoglycans (fig. 3 and table 2). Therefore, ELISA, using the antibodies, could be applied to quantify airway mucin production in future mucoactive drug screening studies.
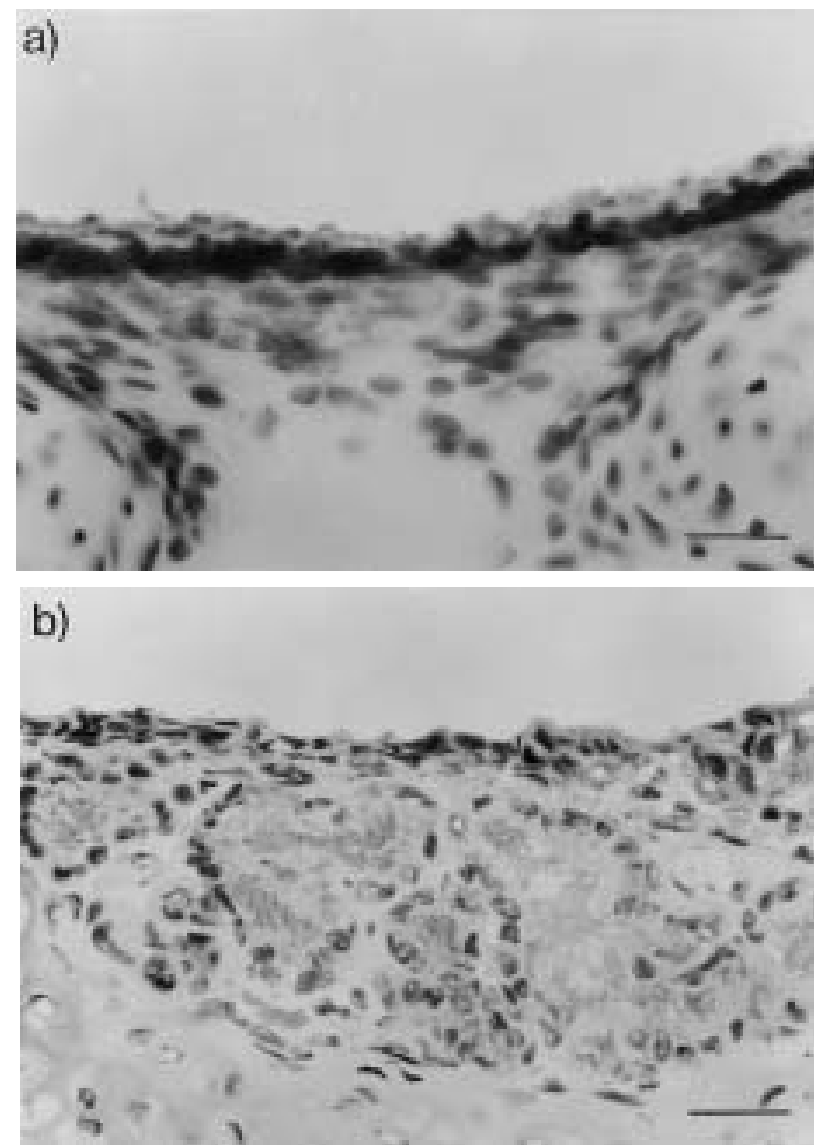

Fig. 2. - Immunohistochemical staining of hamster trachea with monoclonal antibody 4H6: a) 4H6 reacted against tracheal surface secretions in a normal hamster; b) tracheal submucosal gland secretions in a bronchitic hamster haematoxylin counterstain. Internal scale bar $=50 \mu \mathrm{m}$. (Reproduced with permission from [22]). 


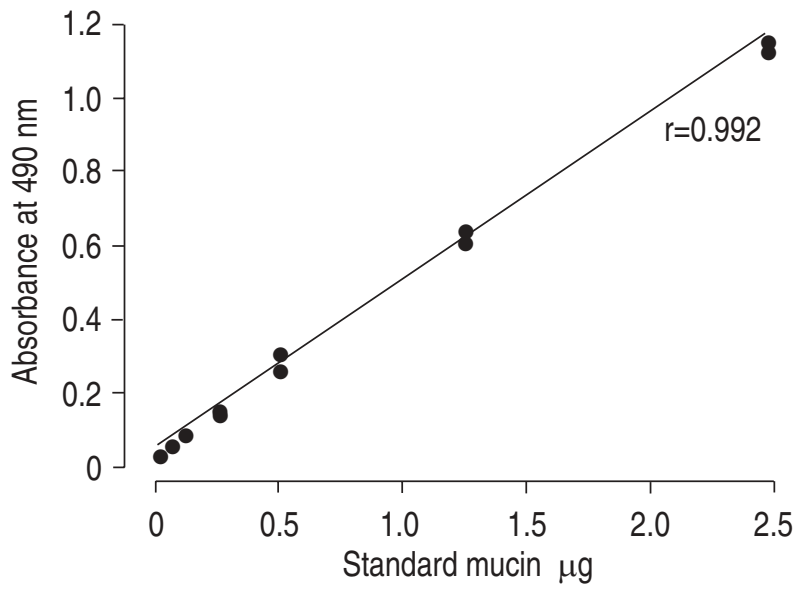

Fig. 3. - Standard curve of enzyme linked immunosorbent assay (ELISA) using purified hamster airway mucin as standard. ELISA was carried out as described previously [22] with different amounts of purified airway mucin as indicated. Antigen-solidificated wells, as indicated, were treated with $100 \mathrm{mM}$ Na periodate in $50 \mathrm{mM}$ acetate buffer $(\mathrm{pH} 4.5)$ for $12 \mathrm{~h}$ at room temperature.

Table 2. - Cross-reactivities of monoclonal antibody $4 \mathrm{H} 6$

\begin{tabular}{llc}
\hline Species & Sources & ELISA \\
\hline Hamster & BALF & + \\
& ILF & + \\
Rat & BALF & + \\
Guinea-pig & BALF & + \\
Dog & BALF & + \\
Pig & Stomach & + \\
Cow & Submaxillary gland & - \\
Human & BALF & + \\
\hline
\end{tabular}

+: positive reaction; -: negative reaction. ELISA: enzyme linked immunosorbent assay; BALF: bronchoalveolar lavage fluid; ILF: intestinal lavage fluid; Stomach: porcine gastric mucin; Submaxillary gland: bovine submaxillary gland mucin. Porcine gastric mucin and bovine submaxillary gland mucin were obtained from commercial sources. (Reproduced with permission from [22]).

In vitro screening systems for airway secretion in inflammation

For drug evaluation, we used two kinds of in vitro model to evaluate mucoactive drugs. To investigate mucous secretions as a major component of the gel layer of airway secretions, we have used culture systems of hamster tracheal epithelial cells or human pulmonary mucoepidermoid carcinoma cell lines (NCl-H292). To investigate pulmonary surfactant as a major component of the sol layer, we have used primary culture of rat alveolar type II cells. KIM and co-workers [23, 24] have reported that hamster tracheal epithelial cells in culture are morphologically and biochemically similar to goblet cells. Using this system, it has been reported that the secretion of high molecular weight glycoconjugates (HMWG), a marker of mucus, is not influenced by pharmacological agents such as acetylcholine or histamine, but is influenced by alteration of the $\mathrm{pH}$ and osmolarity of the medium, cationic proteases, mechanical strain of cells and adenosine triphosphate (ATP) [25-29]. We found that protein kinase $\mathrm{C}$ was involved in HMWG secretion in hamster tracheal epithelial cells in culture [30]. Recently, we have found that adrenergic agonists suppressed HMWG secretion in hamster tracheal epithelial cells (table 3 ).
Table 3. - Effects of pharmacological agents on the secretion of high molecular weight glycoconjugates (HMWG) in primary culture of hamster tracheal epithelial (HTE) cells

\begin{tabular}{lc}
\hline Neurotransmitters & $\begin{array}{c}\text { HMWG secretion } \\
\% \text { control }\end{array}$ \\
\hline Control water & $100.0 \pm 3.6$ \\
ATP $(2 \mathrm{mM})$ & $236.5 \pm 13.6^{*}$ \\
PMA $(10 \mathrm{nM})$ & $226.1 \pm 9.1^{*}$ \\
Norepinephrine $(10 \mu \mathrm{M})$ & $73.2 \pm 3.6^{*}$ \\
Isoproterenol $(10 \mu \mathrm{M})$ & $66.4 \pm 4.1^{*}$ \\
Forskolin $(1 \mu \mathrm{M})$ & $61.3 \pm 4.6^{*}$ \\
8-Br-cAMP $(10 \mu \mathrm{M})$ & $97.1 \pm 7.9^{*}$ \\
\hline
\end{tabular}

HTE cells were incubated with pharmacological agents for 30 min. Each value represents the mean \pm SEM of four samples. *: $\mathrm{p}<0.05$ versus control. ATP: adenosine triphosphate; PMA: phorbol myristate acetate; cAMP: cyclic adenosine monophosphate.

To simulate an inflammatory state, we have used coculture systems of mucous cells with polymorphonuclear leucocytes (PMNLs) activated by several stimuli [31,32]. Abnormal and excessive mucous secretion is a characteristic feature of many chronic inflammatory lung diseases, accompanied by the influx of PMNLs into the airway and release of substance $\mathrm{P}(\mathrm{SP})$ from the peripheral endings of primary sensory neurons. We examined whether PMNLs activated by SP $(10 \mathrm{mM})$ can affect the secretion of HMWG from cultured hamster tracheal epithelial cells. We measured both the released and the cell-associated HMWG. SP-activated PMNLs $\left(10^{6}\right.$ cells $\left.\cdot \mathrm{mL}^{-1}\right)$ reduced the amount of cell-associated HMWG to $76 \%$ of the control level, but did not affect the amount of the released HMWG. The reduction of the amount of cellassociated HMWG was inhibited by ONO-5046, a specific elastase inhibitor (fig. 4). In addition, the HMWG was digested by the activated PMNLs. These findings suggested that SP stimulated the release of cell-associated HMWG, which was then degraded by elastase released from PMNLs activated by SP. As suggested in many reports, we indicated that neutrophil elastase may be a crucial mediator to induce mucous secretion in inflammation.

Pulmonary surfactant, which is composed of phospholipids and apoproteins and is mainly produced in alveolar type II cells, lowers the surface tension at the air-liquid interface in the lung and provides alveolar stability. De Sanctis et al. [33] clearly demonstrated that, in addition to the vital role, surfactants were also important in airway mucociliary clearance. Several studies have suggested that the presence of phospholipids in the airways may modify the clearance of mucus [34-39]. The existence of surfactant films has been demonstrated in the airways of several species by electron microscopy $[36,40]$, and by in situ surface tension measurement $[36,41]$. We also confirmed a protective effect of surface active phospholipids on an acid-inducing inhibition of mucociliary transport in pigeons [42].

Taken together with many reports on pulmonary surfactant in mucociliary clearance, it is reasonable to study the effects of mucoactive drugs on pulmonary surfactant secretion in alveolar type II cells. Secretion of phosphatidylcholine, a major surfactant phospholipid, has been shown to be influenced by a variety of physiological and pharmacological agents in alveolar type II cells $[43,44]$. We also found that both $\beta_{1}$ - and $\beta_{2}$-adrenoceptor subtypes mediated phosphatidylcholine secretion 

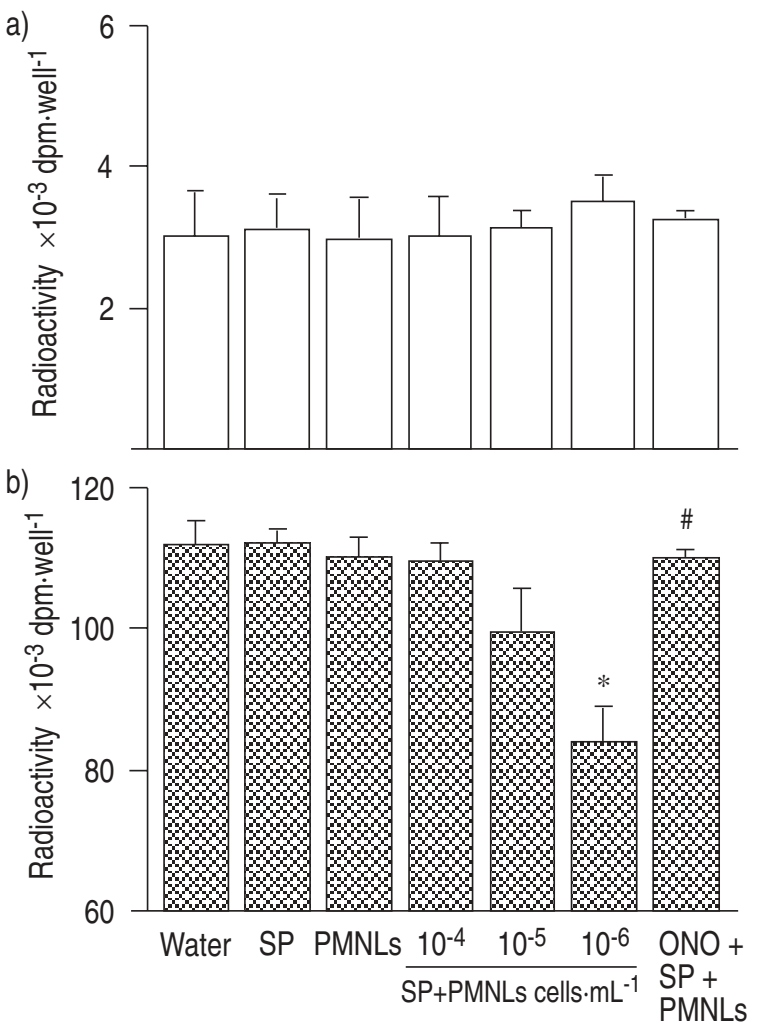

Fig. 4. - Effect of substance P (SP)-activated polymorphonuclear leucocytes (PMNLs) on: a) secretion of $\left[{ }^{3} \mathrm{H}\right]$ high molecular weight glycoconjugates (HMWG); and b) amount of the cell-associated $\left[{ }^{3} \mathrm{H}\right]$ HMWG in cultured hamster tracheal epithelial cells. Cultures were incubated with water, SP $(10 \mu \mathrm{m})$, PMNLs $\left(10^{6}\right.$ cells $\left.\mathrm{mL}^{-1}\right)$, or SPactivated PMNLs $\left(10^{4}\right.$ cells $\cdot \mathrm{mL}^{-1}, 10^{5}$ cells $\cdot \mathrm{mL}^{-1}$ or $10^{6}$ cells $\left.\cdot \mathrm{mL}^{-1}\right)$ for $30 \mathrm{~min}$, or were pretreated with ONO-5046 (ONO; $10 \mathrm{mM})$ for $1 \mathrm{~min}$ before the addition of SP-activated PMNLs $\left(10^{6}\right.$ cells $\left.\cdot \mathrm{mL}^{-1}\right)$. Each value represents the mean \pm SEM of four samples. *: $\mathrm{p}<0.05$ versus control (control, or PMNLs alone); \#: $\mathrm{p}<0.05$ versus SP-activated PMNLs ( $10^{6}$ cells $\left.\cdot \mathrm{mL}^{-1}\right)$. (Reproduced with permission from [31]).

Table 4. - Effect of $\beta$-adrenoceptor antagonists on $\beta$ adrenoceptor agonist-induced secretion of $\left[{ }^{3} \mathrm{H}\right]$ phosphatidylcholine in rat alveolar type II cells

\begin{tabular}{|c|c|c|c|}
\hline \multirow[b]{2}{*}{ Antagonists } & \multicolumn{3}{|c|}{ Secretion \% } \\
\hline & $\begin{array}{l}\text { Isoprenaline } \\
(0.1 \mu \mathrm{M})\end{array}$ & $\begin{array}{c}\text { Dobutamine } \\
(0.1 \mu \mathrm{M})\end{array}$ & $\begin{array}{l}\text { Procaterol } \\
(0.1 \mu \mathrm{M})\end{array}$ \\
\hline Basal secretion & $0.45 \pm 0.05$ & $0.39 \pm 0.04$ & $0.50 \pm 0.07$ \\
\hline No antagonist & $\begin{array}{l}1.22 \pm 0.08 \\
(100)\end{array}$ & $\begin{array}{c}0.96 \pm 0.06 \\
(100)\end{array}$ & $\begin{array}{l}1.24 \pm 0.11 \\
\quad(100)\end{array}$ \\
\hline $\begin{array}{c}\text { Propranolol } \\
(0.1 \mu \mathrm{M})\end{array}$ & $\begin{array}{l}0.78 \pm 0.08 * \\
\quad(42.9)\end{array}$ & $\begin{array}{l}0.54 \pm 0.03 * \\
(26.3)\end{array}$ & $\begin{array}{l}0.65 \pm 0.08 * \\
\quad(20.3)\end{array}$ \\
\hline $\begin{array}{l}\text { Atenolol } \\
\qquad(1.0 \mu \mathrm{M})\end{array}$ & $\begin{array}{l}1.00 \pm 0.09 \\
(71.4)\end{array}$ & $\begin{array}{l}0.56 \pm 0.05^{*} \\
(29.8)\end{array}$ & $\begin{array}{c}1.32 \pm 0.06^{*} \\
(114)\end{array}$ \\
\hline $\begin{array}{l}\text { ICI } 118,551 \\
(0.1 \mu \mathrm{M})\end{array}$ & $\begin{array}{l}0.94 \pm 0.07 \\
\quad(63.6)\end{array}$ & $\begin{array}{c}0.86 \pm 0.04 \\
(82.5)\end{array}$ & $\begin{array}{l}0.61 \pm 0.16^{*} \\
(14.9)\end{array}$ \\
\hline $\begin{array}{l}\text { Atenolol }(1.0 \mu \mathrm{M}) \\
+ \text { ICI } 118,551 \\
(0.1 \mu \mathrm{M})\end{array}$ & $\begin{array}{l}0.68 \pm 0.18 * \\
\quad(29.9)\end{array}$ & $\mathrm{ND}$ & $\mathrm{ND}$ \\
\hline
\end{tabular}

Secretion is expressed as the amount of $\left[{ }^{3} \mathrm{H}\right]$ phosphatidylcholine in the medium as a percentage of that in cells plus medium at the end of the incubation period. The percentage change in the secretion attenuated by antagonists was obtained from the comparison with the effect of agonists alone, as shown in parentheses. Antagonists were added 5 min before the addition of agonists. The data are presented as mean \pm SEM from four to six experiments and were analysed statistically with Duncan's multiple-range test. *: $\mathrm{p}<0.05$ as compared to control group values. ND: not done.

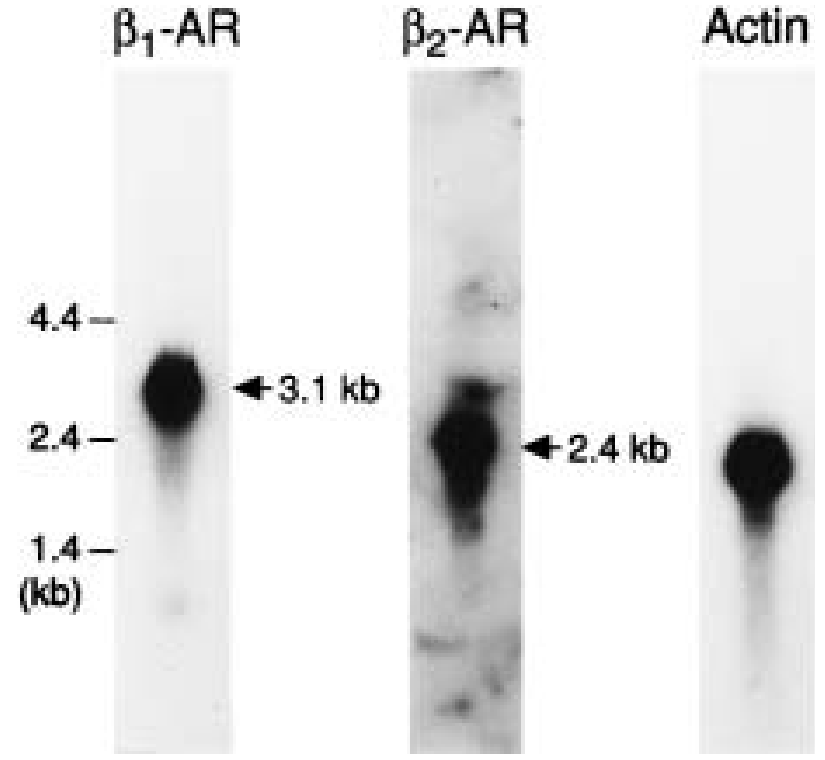

Fig. 5. - Northern blot analysis of $\beta_{1}$ - and $\beta_{2}$-adrenoceptor messenger ribonucleic acid (mRNA) in rat alveolar type II cells. Five micrograms of poly (A) ribonucleic acid (RNA) from primary cultured alveolar type II cells were electrophoresed on formaldehydeagarose gel, transferred to a nylon membrane. The blot was hybridized with $\left.{ }^{32} \mathrm{P}\right] \mathrm{dCTP}$-labelled $\beta_{1}$ - $\left(\beta_{1}\right.$-AR), $\beta_{2}$-adrenoceptor $\left(\beta_{2}\right.$-AR) or $\beta$ actin complementary deoxyribonucleic acid (cDNA) probes. The probes for adrenoceptors were as follows: $\beta_{1}$-AR, Pst I fragment $(900 \mathrm{bp})$ of rat cDNA; $\beta_{2}$-AR, Sma I - Hind III fragment $(1.3 \mathrm{~kb})$ of hamster cDNA. The membrane was washed, and autoradiographed at $-70^{\circ} \mathrm{C}$ for 2-4 days.

(table 4) [45] and confirmed that both $\beta_{1}$ - and $\beta_{2}$-adrenoceptor genes were expressed in rat alveolar type II cells (fig. 5) [46].

To simulate inflammatory states, we have used co-culture systems of alveolar type II cells with activated PMNLs or eosinophils [47, 48]. Activated PMNLs and eosinophils in airway epithelium are thought to be involved in the pathogenesis of many airway diseases. PMNLs or eosinophils activated by opsonized zymosan caused a significant increase in phosphatidylcholine secretion. Pretreatment of the culture with the combination of superoxide dismutase and catalase reduced the increase in phosphatidylcholine secretion (data on activated eosinophils shown in figures 6 and 7). These results suggested that activated PMNLs and eosinophils stimulated the secretion of pulmonary surfactant, and that the stimulation was partly mediated by oxygen radicals. These systems may be useful to assay the antioxidant effects of mucoactive drugs, although it remains unclear whether the increased pulmonary surfactant plays a defensive role in inflammation.

\section{Mucociliary transport in inflammation}

Mucociliary clearance is an important pulmonary defense mechanism that serves to remove inhaled substances from the lung [49]. The mucociliary function is depressed by a variety of water-soluble atmospheric pollutants such as $\mathrm{SO}_{2}$ and nitrogen dioxide $\left(\mathrm{NO}_{2}\right)$ [49]. The techniques for in vivo measurement of mucous transport rates involve the placement of an optically, radiographically, or scintigraphically detectable solid or liquid marker on the mucosa [50]. 

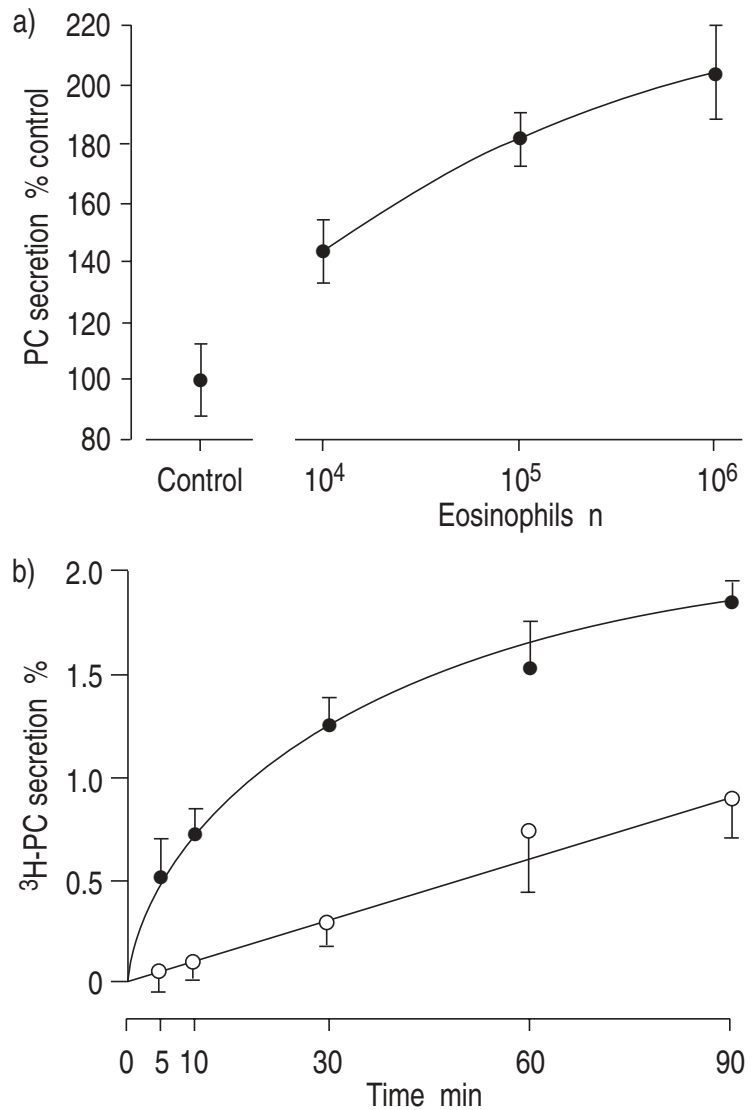

Fig. 6. - a) Phosphatidylcholine secretion from rat alveolar type II cells in response to the number of activated eosinophils by opsonized zymosan $\left(100 \mathrm{mg} \cdot \mathrm{mL}^{-1}\right)$. Data are the mean \pm SEM of five experiments. b) Time course of phosphatidylcholine secretion stimulated by activated eosinophils $\left(10^{5}\right.$ cells $\left.\cdot \mathrm{mL}^{-1}\right)$ by opsonized zymosan $\left(100 \mathrm{mg} \cdot \mathrm{mL}^{-1}\right)$ in alveolar type II cells. $\left[{ }^{3} \mathrm{H}\right]$ phosphatidylcholine secretion is expressed as an amount of $\left[{ }^{3} \mathrm{H}\right]$ phosphatidylcholine in the medium as the percentage of that in cells plus medium at the end of incubation period. Data are the mean \pm SEM of four experiments. (Reproduced with permission from [48]).

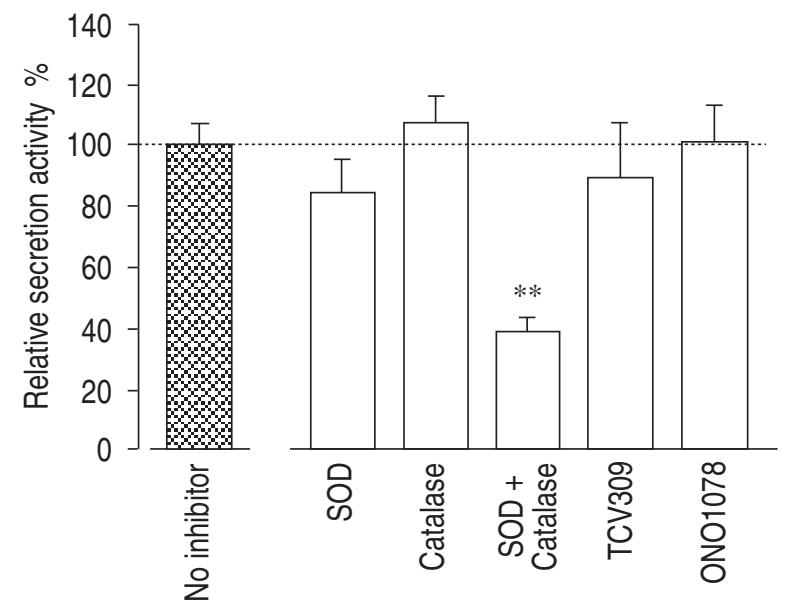

Fig. 7. - Effects of several inhibitors on phosphatidylcholine secretion induced by activated eosinophils. Inhibitors of eosinophil products were added $10 \mathrm{~min}$ before eosinophils $\left(10^{5} \mathrm{cells} \cdot \mathrm{mL}^{-1}\right)$ and opsonized zymosan $\left(100 \mathrm{mg} \cdot \mathrm{mL}^{-1}\right)$ were applied and the incubation was continued for $90 \mathrm{~min}$. As inhibitors of eosinophil products, superoxide dismutase (SOD; 2 units $\left.\cdot \mathrm{mL}^{-1}\right)$, catalase (1000 units $\left.\cdot \mathrm{mL}^{-1}\right)$, TCV309 $(1 \mathrm{mM}$, PAF receptor antagonist) and ONO1078 (1 mM, leukotriene $\mathrm{D}_{4}\left(\mathrm{LTD}_{4}\right)$ receptor antagonist) were used. Relative secretion activity was expressed as a percentage of the values for activated eosinophils without inhibitors. Each value represents the mean \pm SEM of five experiments. $* *: \mathrm{p}<0.01$ $v s$ no inhibitor. (Reproduced with permission from [48]).
To simulate inflammatory states, we have used pigeons and quails for the evaluation of drugs on mucociliary transport. A major reason for the use of birds is based on histological findings and biochemical study of bronchoalveolar lavages. As shown in figure 8, the histological features are similar to airway inflammatory states, because there are many proliferated goblet cells and submucosal glands in tracheal epithelium. Furthermore, in bronchoalveolar lavages of birds, an extremely high content of fucose, a typical sugar in mucins, was found (table 5). So far, we have examined the effects of many mucoactive drugs on mucociliary clearance in birds [16, 19, 42, 51-58]. For example, we found that inhalation of bromhexine, classified as a mucolytic agent, increased mucociliary transport in quails (fig. 9). Recently, we investigated the effect of leukotriene $\mathrm{D}_{4}\left(\mathrm{LTD}_{4}\right)$ on mucociliary transport in quails [58]. As shown in figure 10, a topical application of $\operatorname{LTD}_{4}(0.2-2 \mathrm{ng})$ to tracheal mucosa resulted in a dose-dependent increase in mucociliary transport 5 or $10 \mathrm{~min}$ after the application. Forty minutes after the application of 2 ng of $\mathrm{LTD}_{4}$, the mucociliary transport was decreased to about $84 \%$ of that in
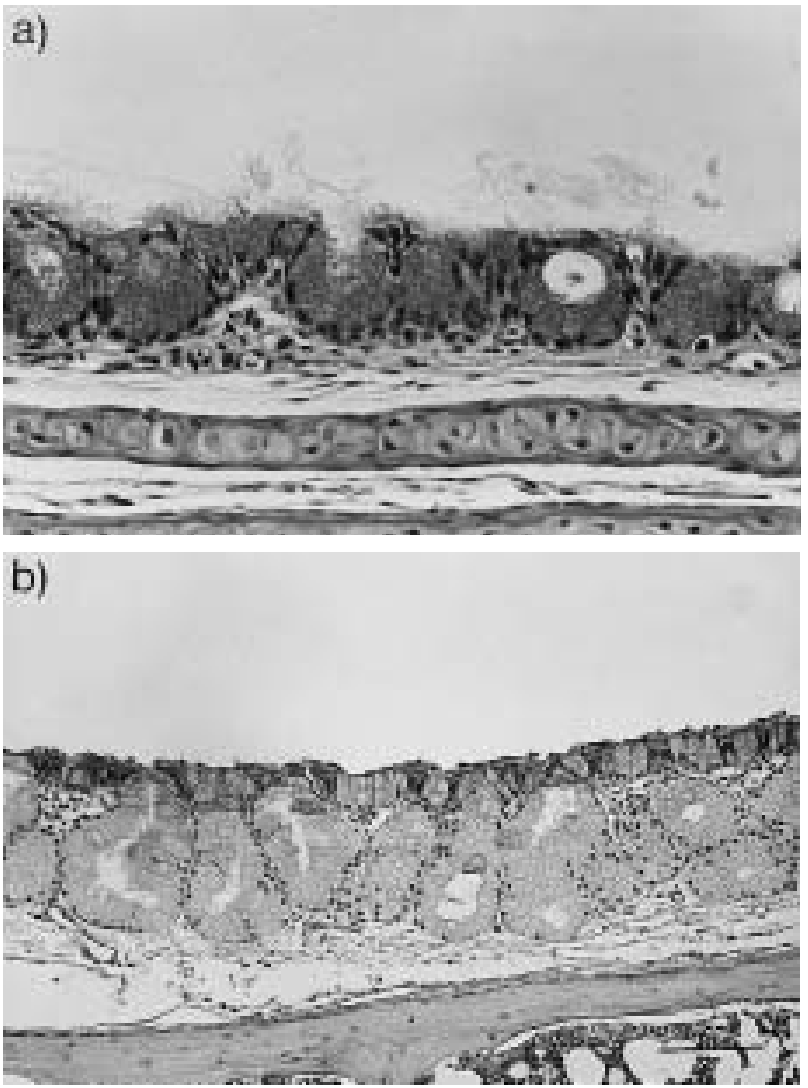

Fig. 8. - Haematoxilin eosin section of tracheal tissues in: a) quail; and $\mathrm{b}$ ) pigeon. Internal scale $\mathrm{bar}=50 \mu \mathrm{m}$.

Table 5. - Biochemical components of bronchoalveolar lavages of quail, pigeon and rat

\begin{tabular}{|c|c|c|c|c|c|}
\hline \multirow[b]{2}{*}{ Animals } & \multicolumn{5}{|c|}{ Components $\mathrm{mg} \cdot \mathrm{mL}^{-1}$} \\
\hline & Protein & Fucose & NANA & $\mathrm{PC}$ & DSPC \\
\hline Ouail & $182.7 \pm 21.6$ & $25.4 \pm 3.8$ & $1.7 \pm 0.2$ & $30.9 \pm 4.1$ & $26.5 \pm 1.6$ \\
\hline Pigeon & $108.5 \pm 24.6$ & $7.0 \pm 0.4$ & $1.4 \pm 0.2$ & $30.9 \pm 5.1$ & $23.4 \pm 7.1$ \\
\hline Rat & $155.9 \pm 37.9$ & $2.4 \pm 0.2$ & $2.0 \pm 0.2$ & $46.2 \pm 8.6$ & $36.4 \pm 3.4$ \\
\hline
\end{tabular}

NANA: N-acetylneuraminic acid; PC: phosphatidylcholine; DSPC: disaturated phospatidylcholine. 


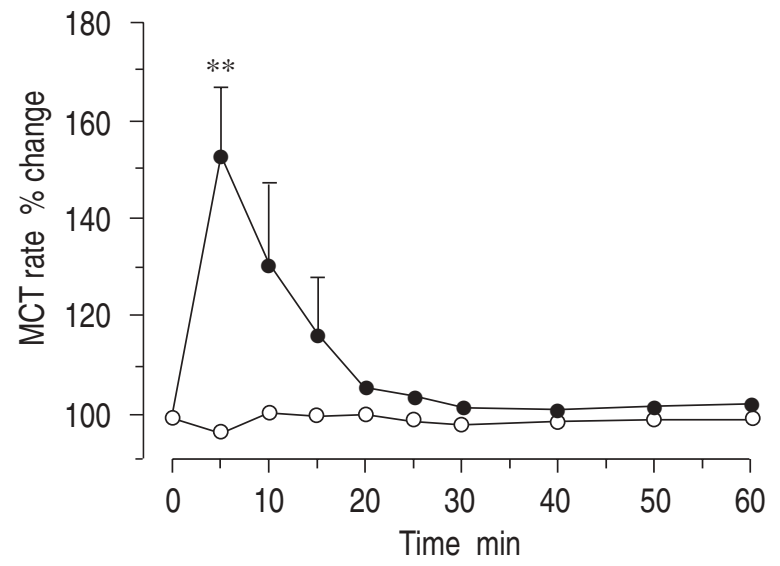

Fig. 9. - Effect of bromhexine on mucociliary transport (MCT) in pigeons. Values are expressed as a percentage of pre-application values. Bromhexine $(0.2 \%)$ was nebulized to tracheal mucosa for $10 \mathrm{~min}$. Each value represents the mean \pm SEM of six animals. $\bigcirc$ : Control; $\bullet$ : $0.2 \%$ bromhexine. $* *: \mathrm{p}<0.01$, statistically significant difference from the control value (Dunnett's t-test).

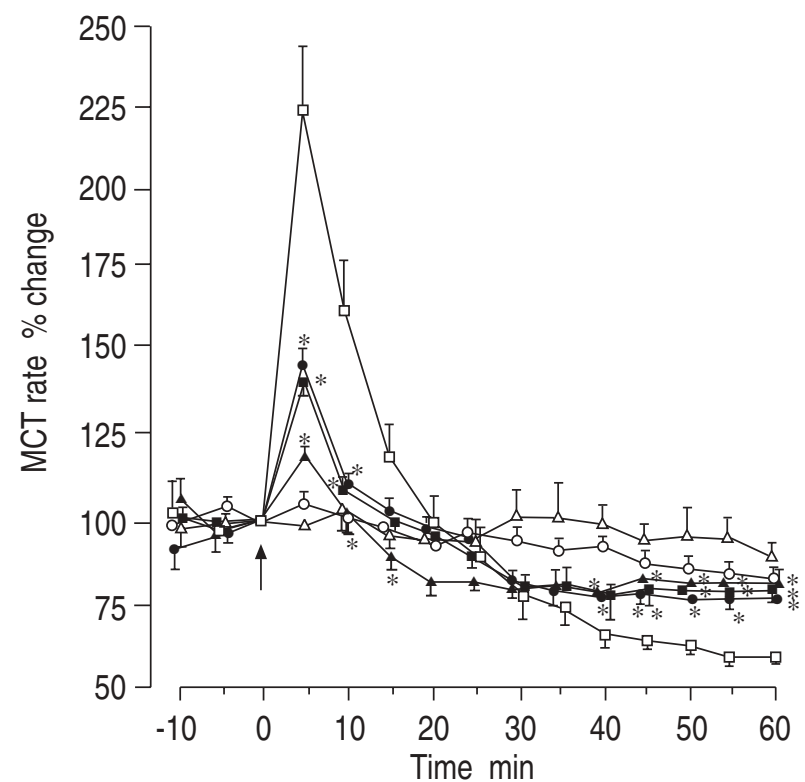

Fig. 10. - Inhibitory effect of ONO-1078, a leukotriene $\mathrm{D}_{4}\left(\mathrm{LTD}_{4}\right)$ receptor antagonist, on $\mathrm{LTD}_{4}$-induced changes in mucociliary transport (MCT). Values are expressed as a percentage of preapplication values. Each value represents mean \pm SEM of six animals. $-\infty$ : con-

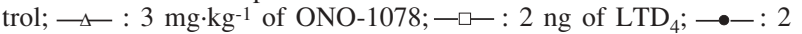
ng of $\mathrm{LTD}_{4}$ and $0.03 \mathrm{mg} \cdot \mathrm{kg}^{-1}$ of ONO-1078; $-1: 2 \mathrm{ng}$ of $\mathrm{LTD}_{4}$ and $0.3 \mathrm{mg} \cdot \mathrm{kg}^{-1}$ of ONO-1078; —- : $2 \mathrm{ng}$ of $\mathrm{LTD}_{4}$ and $3 \mathrm{mg} \cdot \mathrm{kg}^{-1}$ of ONO-1078. *: $\mathrm{p}<0.05$, statistically significant difference from the $2 \mathrm{ng}$ of $\mathrm{LTD}_{4}$ group (Dunnett's t-test). (Reproduced with permission from [58])

the control group. Both the transient increase and the subsequent decrease were blocked by ONO-1078 (0.03$3 \mathrm{mg} \cdot \mathrm{kg}^{-1}, i . m$.), a specific $\mathrm{LTD}_{4}$ receptor antagonist. These results suggested that $\mathrm{LTD}_{4}$ had a biphasic effect on tracheal mucociliary transport through leukotriene receptors. Moreover, we found that topical application of histamine $(1 \mathrm{pmol})$ to tracheal mucosa markedly decreased mucociliary transport 5 or 10 min after the application. The inhibitory effect was prevented by the anti-allergic drug ketotifen (fig. 11).

In preliminary experiments, we found that sphingomyelin-rich lipid fractions from sputa suppressed mucociliary

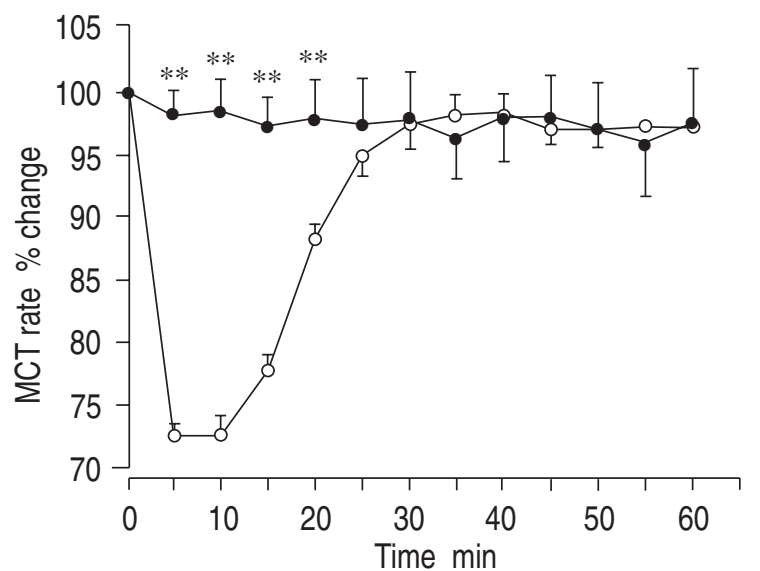

Fig. 11. - Effect of ketotifen, an anti-allergic drug, on the mucociliary transport impaired by histamine in quails. Histamine (1 pmol) was applied topically to tracheal mucosa. Ketotifen $\left(1 \mathrm{mg} \cdot \mathrm{kg}^{-1}\right)$ was administered orally, $1 \mathrm{~h}$ before histamine application. Values are expressed as a percentage of preapplication values. Each value represents the mean \pm SEM of six animals. $\bigcirc$ : histamine; $\bullet$ : ketotifen. **: $\mathrm{p}<0.01$, statistically significant difference from the histamine-applied values (Dunnett's t-test).

transport in the trachea [59]. Although the mechanism of action remains unclear, the finding suggests that we have to consider composition of phospholipids in sputa as inhibitory factors of mucociliary clearance.

\section{Current mucoactive drugs}

We have evaluated several mucoactive drugs over two decades. Of these, we introduce here the following drugs with anti-inflammatory properties: sodium aceneuramate; glucocorticoids; traditional Chinese medicines; and new cysteine derivatives.

\section{Sodium aceneuramate ( $N$-acetylneuraminic acid (NANA) sodium salt)}

Although the participation of sialic acids, mainly NANA, in many biological and pathological processes has been well documented [60], there are only a few studies concerning the significance of the sialic acid in the airway [61]. Using a selected ion monitoring technique, we found that the sputa of bronchitic rabbits contained much higher levels of both free and bound NANA than the airway secretions of normal rabbits $[62,63]$. In addition, we found that NANA concentrations in the sputa of patients with chronic bronchitis (free: 15-204 $\mathrm{mg} \cdot \mathrm{mL}^{-1}$; bound: $276-1298 \mathrm{mg} \cdot \mathrm{mL}^{-1}$ ) were also apparently higher than those in the bronchoalveolar lavages of healthy subjects. Furthermore, we have reported that an inhalation of NANA repaired inflammation in the airway (fig. 12), and caused bronchitic rabbits to produce sputa with a low viscosity, similar to normal airway secretions [20,63]. Furthermore, NANA, but not lactose, protected the mucociliary transport impaired by cigarette smoke in a dose-dependent manner (fig. 13) [54]. The results suggest that NANA may participate in the defense mechanism in the airway against irritant gases. In addition, we studied the in vivo anti-allergic effect of NANA in guinea-pigs passively sensitized with anti-ovalbumin rabbit serum [64]. NANA inhibited bronchial 


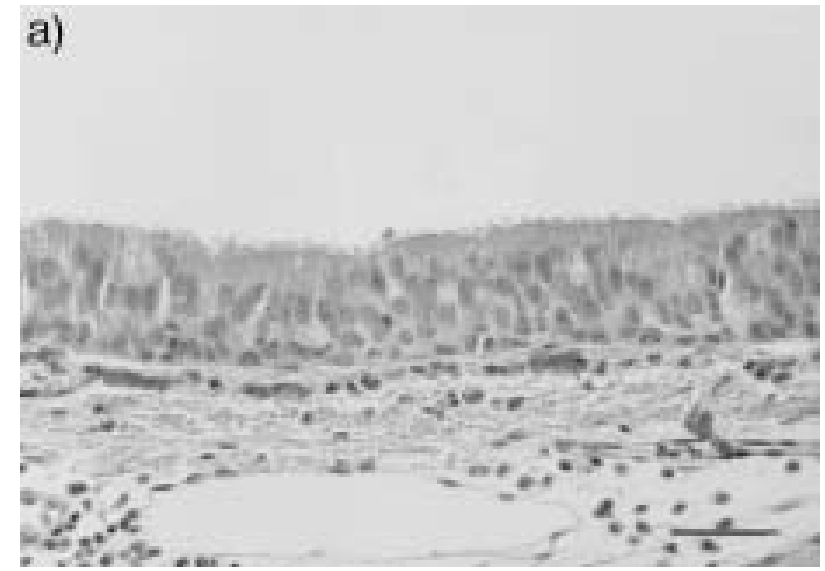

b)

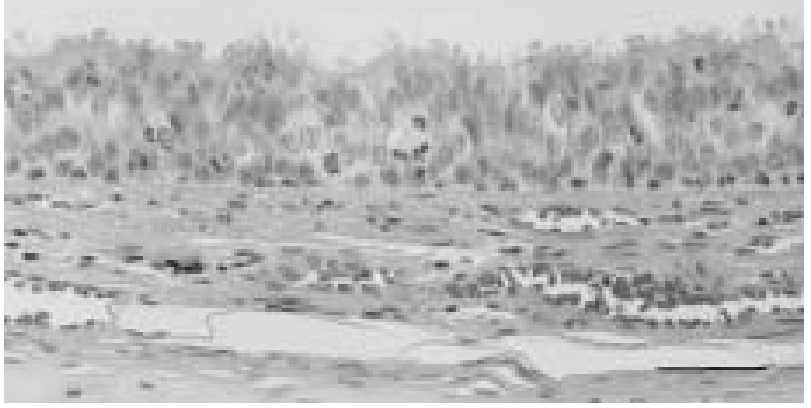

Fig. 12. - Haematoxylin eosin section of tracheal tissues of bronchitic rabbits repeatedly administered: a) $\mathrm{N}$-acetylneuraminic acid (NANA); or b) saline for 3 weeks. Internal scale bar $=50 \mu \mathrm{m}$. (Reproduced with permission from [20)].

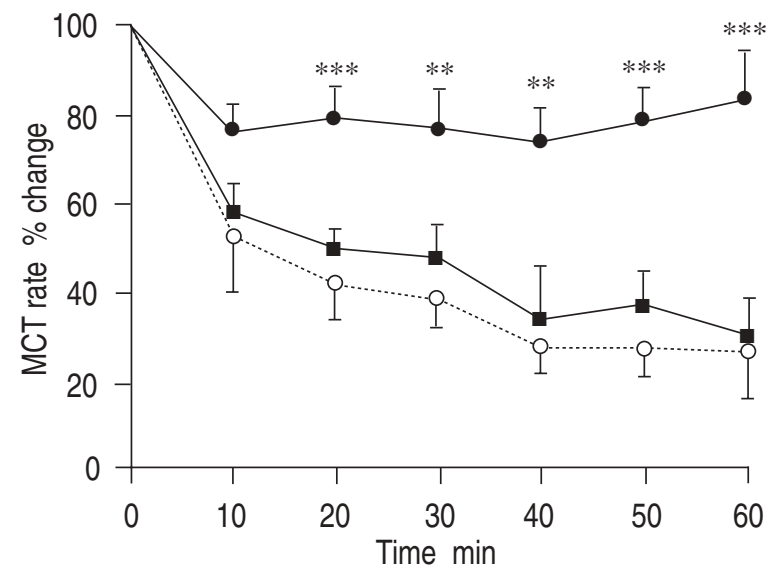

Fig. 13. - Effects of N-acetylneuraminic acid (NANA) and lactose $\left(50 \mathrm{mg} \cdot \mathrm{mL}^{-1}\right)$ on mucociliary transport (MCT) impaired by cigarette smoke exposure. The time course of percentage changes in the MCT rate after cigarette smoke exposure, which was obtained from comparison with the mean value of the MCT rate during 20 min before the treatment, is shown. Vertical bars indicate standard errors. The statistical analysis between NANA ( $\bullet-)$ - and distilled water ( $\multimap-$ )or lactose $(\rightarrow-)$-treated groups was performed using the unpaired t-test. **, ***: $\mathrm{p}<0.01, \mathrm{p}<0.001$ ). (Reproduced with permission from [54]).

anaphylaxis and the release of histamine into bronchoalveolar lavages (fig. 14). NANA dose-dependently attenuated heterologous passive cutaneous anaphylaxis and haemorrhaging in the passive Arthus reaction (fig. 15). Interestingly, NANA did not inhibit the release of a)

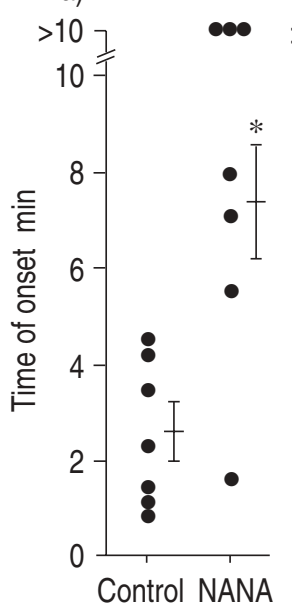

b)

c)

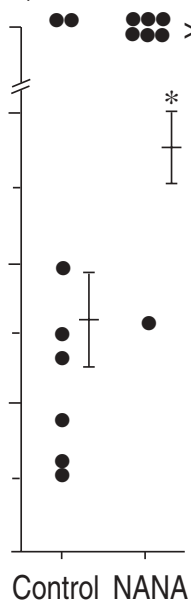

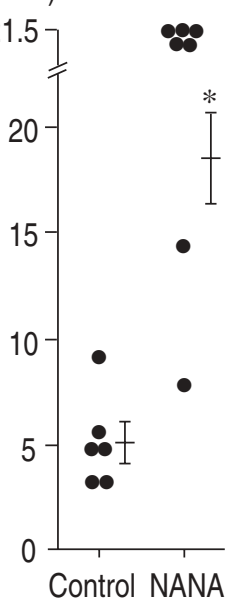

Fig. 14. - Effect of N-acetylneuraminic acid (NANA) on bronchial anaphylaxis provoked by inhalation of ovalbumin: a) $1 \mathrm{mg} \cdot \mathrm{mL}^{-1}$ for $10 \mathrm{~min}$; b) $5 \mathrm{mg} \cdot \mathrm{mL}^{-1}$ for $3 \mathrm{~min}$; c) $10 \mathrm{mg} \cdot \mathrm{mL}^{-1}$ for $1.5 \mathrm{~min}$ and treatment with three antagonists, in passively sensitized guinea-pigs. The three antagonists were: $2.5 \mathrm{mg} \cdot \mathrm{kg}^{-1}$ pyrilamine; $1 \mathrm{mg} \cdot \mathrm{kg}^{-1}$ propranolol; and $1 \mathrm{mg} \cdot \mathrm{kg}^{-1}$ atropine, i.v. NANA $\left(20 \mathrm{mg} \cdot \mathrm{kg}^{-1}\right)$ or saline $\left(1 \mathrm{~mL} \cdot \mathrm{kg}^{-1}\right)$ was administered, i.v., $30 \mathrm{~min}$ before antigen exposure. The time of onset of dyspnoea and mortality were determined with the tidal volume measured by body plethysmography. If a guinea-pig did not die within the observation period (10 or 3 min without treatment or 21.5 min with treatment), the onset time was taken as the time of termination of the observation. In the guinea-pigs treated with three antagonists (c) death occurred in $100 \%$ of controls and $14.3 \%$ of NANA treated animals. $*: p<0.05$, statistically significant difference from the control values (Student's t-test). Vertical bars represent the mean \pm SEM. (Reproduced with permission from [64]).
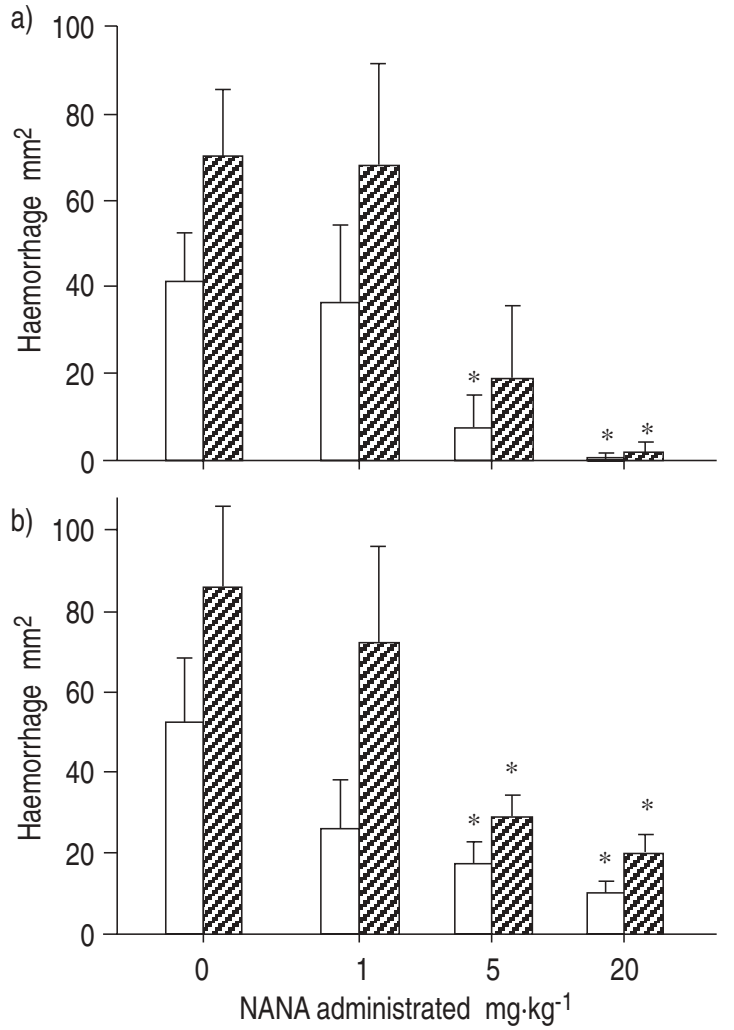

Fig 15 - Effect of $\mathrm{N}$-acetylneuraminic (NANA) on the passive Arthus reaction. NANA or saline was administered i.v., $30 \mathrm{~min}$ before the antigenic challenge. The doses of the antigen were $0.025(\square)$ and $0.05 \mathrm{mg} \cdot \mathrm{site}^{-1}(\not{Z})$. Data are presented as mean \pm SEM for six experiments. *: $\mathrm{p}<0.05$, statistically significant difference from the control values (Dunnett's t-test). Reproduced with permission from [64]. 
histamine from sensitized minced lung tissues in vitro. The clinical observations that NANA is an effective inhalant expectorant seem to support our findings $[65$, 66]. We administered NANA (2 $\mathrm{mg}$, b.i.d. for 7 days) by inhalation to ten patients with bronchiectasis, chronic bronchitis, diffuse panbronchiolitis and other respiratory diseases that cause sputa [66]. We found that NANA improved subjective symptoms, such as the expectoration and sticking sensation of sputa. The viscosity of sputa was increased in four patients and the ratio of disaturated phosphatidylcholine (DSPC)/phosphatidylcholine (PC) was increased in five patients, but protein contents were decreased in four patients whose subjective symptoms were improved. NANA did not cause any side-effects or abnormal laboratory findings. Therefore, it is possible that NANA improved the subjective respiratory symptoms due to sputa.

\section{Glucocorticoids}

Glucocorticoids are first-choice drugs in the management of the inflammatory process seen in asthma. Although current pharmacological approaches to airway mucus production are limited, glucocorticoids seem to be the most effective among a few useful drugs. However, there are a few studies documenting the benefits of glucocorticoid therapy on the mucociliary clearance and the excessive production of airway mucus. Systemic administration of glucocorticoids ameliorated bronchial obstruction and facilitated expectoration in patients with asthma and chronic bronchitis, although they did not alter sputum viscosity [67]. Direct exposure of the bronchial mucosa to prednisolone resulted in mild cilioexcitation [68], whereas the topical application of beclomethasone had no effect on mucociliary transport in conscious sheep [67]. Thus, the contribution of glucocorticoids to mucociliary transport remains unclear. We previously examined the effect of corticosterone on tracheal mucociliary transport in pigeons (fig. 16) [56]. Corticosterone $\left(5.0 \mathrm{mg} \cdot \mathrm{kg}^{-1}\right)$ significantly increased the mucociliary transport rate. Metyrapone, an adrenal 11-b steroid hydroxylase inhibitor, significantly decreased the mucociliary transport rate, and the inhibitory action was blocked by $1.0 \mathrm{mg} \cdot \mathrm{kg}^{-1}$ of corticosterone. The findings suggested that glucocorticoids modulated the mucociliary clearance, especially in diseases associated with a decreased level of endogenous corticosteroids.

With regard to effects on mucous production, several reports have shown that glucocorticoids directly reduce submucosal gland secretions [69-72] without a significant alteration in the synthesis of mucins [71]. Recently we tried to clarify the effect of dexamethasone on mucus production and mucin gene expression in a human pulmonary mucoepidermoid carcinoma cell line (NCI-H292) [73]. Dexamethasone $\left(10^{-8}-10^{-6} \mathrm{M}\right)$ significantly suppressed the basal production of $\left[{ }^{3} \mathrm{H}\right]$ glucosamine- or $\left[{ }^{3} \mathrm{H}\right]$ serine-labelled HMWG in NCI-H292 cells (data not shown). To examine the effect on mucin gene expression, we have selected MUC-2 and MUC-5 out of eight mucin genes (MUC-1-MUC-8) [74-86], because MUC-2 was expressed in the airways of patients with inflammatory airway disorders, such as cystic fibrosis and

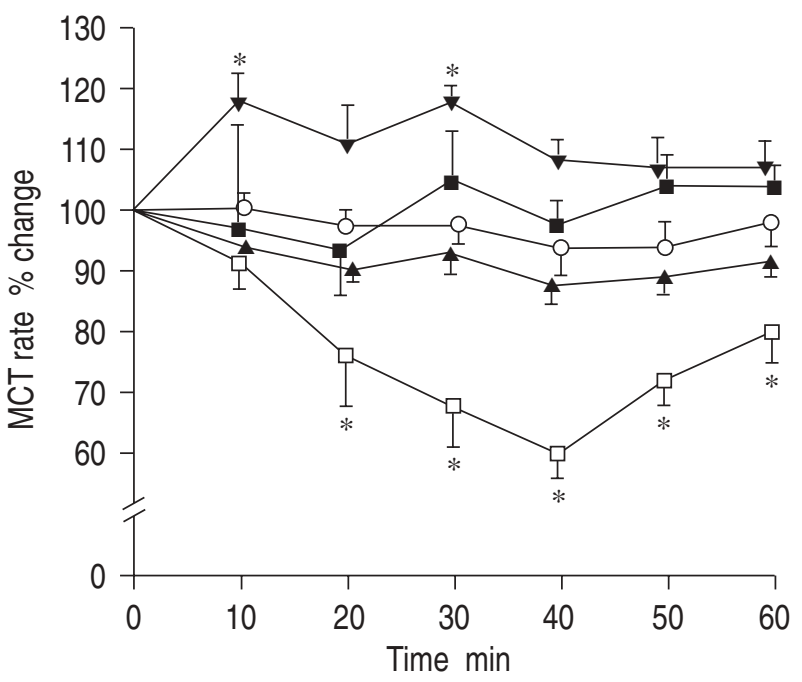

Fig. 16. - Effects of corticosterone and metyrapone on mucociliary transport (MCT) in pigeons. The time course of percentage changes in the MCT rate after administration, obtained from comparison with the mean value of the MCT rate during $20 \mathrm{~min}$ before the treatment, is shown. - : control group; $\multimap$ : corticosterone, $1 \mathrm{mg} \cdot \mathrm{kg}^{-1}$, i.m; $\longrightarrow$ : corticosterone, $5 \mathrm{mg} \cdot \mathrm{kg}^{-1}, \mathrm{i} . \mathrm{m} ; \multimap \square:$ metyrapone, $150 \mathrm{mg} \cdot \mathrm{kg}^{-1}$, i.m; - - metyrapone and corticosterone, $1 \mathrm{mg} \cdot \mathrm{kg}^{-1}$. The values are presented as mean士sem from six experiments. *: $\mathrm{p}<0.05$ versus control group. (Reproduced with permission from [56]).

chronic bronchitis [87-90], and because MUC-5 was cloned from the human airway [83]. In Northern blot analysis, dexamethasone $\left(10^{-9}-10^{-7} \mathrm{M}\right)$ attenuated steady-state messenger ribonucleic acid (mRNA) levels of MUC-2 and MUC-5 mucin genes (data not shown). Thus, we concluded that dexamethasone suppressed the basal production of HMWG and decreased steady-state mRNA levels of mucin genes in airway mucus-producing cancer cells.

\section{Traditional Chinese medicines}

There is an increasing usage of traditional Chinese herbal medicines in clinics and hospitals, because they tend to have moderate side-effects and sometimes produce remarkable efficacy. In order to renormalize overall defects in airway disorders, Chinese medicines may be adequate drugs, because the medicines are composed of various herbs with weak, but ubiquitous pharmacological activities.

Qing-Fei-Tang. This preparation of 16 herbs was described in "Wang Bin Hui Chun", the medical literature published in 1587 in China. Qing-Fei-Tang has been clinically applied in the treatment of chronic obstructive pulmonary diseases with severe cough and sputum. QingFei-Tang was also effective for the treatment of the bronchitis with an asthmatic attack-like symptom [91]. In this patient, the abnormally elevated chemiluminescence of oxygen radicals in leucocytes was normalized as symptoms improved during administration of QingFei-Tang for 5 weeks. Our previous study showed that Qing-Fei-Tang inhibited the release of slow-reacting substance of anaphylaxis from passively sensitized guineapig lung after antigen challenge [59]. Qing-Fei-Tang also suppressed the chemiluminescence of oxygen radicals, when healthy human leucocytes were stimulated 
by opsonized zymosan. In normal rabbits, Qing-Fei-Tang increased the output volume and fatty acid content in airway secretions. In the bronchitic rabbits, administration of Qing-Fei-Tang for 6 weeks restored the decreased amount of saturated fatty acid in the sputa, and histological examinations revealed an amelioration of the inflammation of lung tissues. In pigeons, Qing-Fei-Tang facilitated tracheal mucociliary transport. Accordingly, Qing-Fei-Tang seems to exert effectiveness via its multiple mechanisms.

Mai-men-Dong-Tang. As another Chinese traditional medicine, we have investigated Mai-men-Dong-Tang, consisting of 6 herbs, Ophiopogonis tuber, Pinelliae tuber, Zizyphi fructus, Glycyrrhizae radix, Ginseng radix and Oryzae fructus. Mai-men-Dong-Tang has been used for the treatment of bronchitis and pharyngitis accompanying severe dry cough. We found that unlike codeine, Maimen-Dong-Tang had a notable antitussive activity against the cough associated with bronchitis and the cough increased by angiotensin-converting enzyme inhibitors [92]. Recently, we found that, in alveolar type II cells, Mai-men-Dong-Tang attenuated phosphatidylcholine secretion increased by oxygen radicals from activated PMNLs. In addition, we found that Mai-men-Dong-Tang by itself, slightly stimulated phosphatidylcholine secretion (fig. 17) and increased $\beta_{1}$-adrenoceptor gene expression in rat alveolar type II cells. The mechanism of action remains unclear, but the effect may contribute to its effectiveness in the treatment of airway diseases.

\section{New cysteine derivatives}

We are developing a new cysteine derivative, S-(3hydroxypropyl)-L-cysteine (SS320A), as a new mucoactive drug [93]. In rabbits, SS320A significantly increased pulmonary secretion of the marker dye, indicating bronchosecretagogue activity. In addition, SS320A increased the volume of airway secretions in normal rabbits collected by the Perry and Boyd method. SS320A $\left(10^{-2} \mathrm{M}\right)$ did not influence the rheological properties of the pig gastric mucin in vitro. SS320A (500 $\mathrm{mg} \cdot \mathrm{kg} \cdot \mathrm{day}$, p.o., 2 weeks) restored the decreased content of free sialic acid

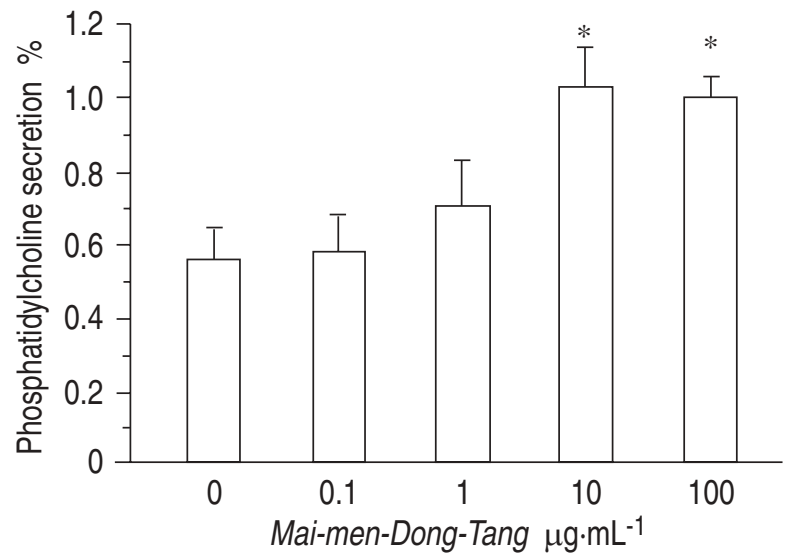

Fig. 17. - Effect of Mai-men-Dong-Tang on $\left[{ }^{3} \mathrm{H}\right]$ phosphatidylcholine secretion in alveolar type II cells. Secretion is expressed as the amount of $[3 \mathrm{H}]$ phosphatidylcholine in the medium as a percentage of that in cells plus medium at the end of the incubation period. The data are presented as mean \pm SEM from four to six experiments and were analysed statistically with Duncan's multiple-range test. *: $\mathrm{p}<0.05$ versus control group values. in bronchoalveolar lavages in animals with bronchitis induced by long term $\mathrm{SO}_{2}$ exposure. SS320A inhibited the hyperplasia of goblet cells in airway epithelium caused by isoproterenol (0.05 $\mathrm{mg} \cdot \mathrm{kg}$, i.p.). SS320A (500 $\mathrm{mg} \cdot \mathrm{kg}^{-1}$, p.o.) did not affect the normal tracheal mucociliary transport in quails, while inhalation of SS320A dosedependently restored the mucociliary transport impaired by cigarette smoke exposure. The results suggest that SS320A possesses mucoactive and mucoregulatory activity.

Erdosteine, (di-S-(2(N-3-(2-oxotetrahydrothienyl)acetamine)) thioglycolic acid; under development in Japan as KW-9144) is a novel thiol derivative with mucolytic, mucomodulatory and free radical scavenging properties, and without gastric adverse effects, unlike other cysteine derivatives [94]. We found that erdosteine $\left(600 \mathrm{mg} \cdot \mathrm{kg}^{-1}\right.$, p.o.) significantly promoted mucociliary transport in quails and suppressed capsaicin-induced cough reflex [95].

Several studies reported two new cysteine derivatives, S-carboxymethylcysteine-lysine salt [96, 97], N-acetylcysteine L-lysinate (Nacystelyn) [98], for water-soluble pharmaceutical forms. Because of the lysine, the compounds are better tolerated by the gastroenteric tract than other mucoactive drugs. This allows the administration of the drug at higher doses, resulting in more effectiveness of the drugs in clinical use. We are also investigating the cysteine derivatives in our systems.

\section{Future directions}

Various parameters (chemical properties, physical properties, mucous production, surfactant phospholipid production, and mucociliary clearance) are considered to be important for the dynamics and the mobilization of airway secretions. Pharmacological investigation, with appropriate techniques, of the ability of an agent to modify these parameters can provide useful information about its mechanism of action. However, since these parameters are strictly interconnected, it is very complicated to elucidate the precise mechanism of action of mucoactive drugs. This means that the goal of the treatment cannot always be achieved by the modification of a single parameter, but should, more realistically, be aimed at a renormalization of several parameters. On the basis of this idea, it will be taken for granted that glucocorticoids are ideal mucoactive drugs, because they possess various pharmacological effects in the lung. From polypharmacological points of view, a traditional Chinese medicine can be classified as a glucocorticoid-like drug because Chinese medicines consist of many kinds of active components that have various pharmacological effects.

As one future course of research, we believe that the efforts to seek compatible actions between glucocorticoids and oriental medicines may lead us to a new opportunity for development of ideal mucoactive drugs with specified actions, i.e. suppression of gene expression.

\section{References}

1. Braga PC, Ziment I, Allegra L. Classification of agents that act on bronchial mucus. In: Braga PC, Allegra L, 
eds. Drugs in Bronchial Mucology. New York, Raven Press, 1989, pp. 59-67.

2. Cerutti P, Kapanci Y. Effects of metabolite VIII of bromhexine (Na872) on type II epithelium of the lung. An experimental and morphological study with reference to surfactant secretion. Respiration 1979; 37: 241-251.

3. Bernard GR. N-acetylcysteine in experimental and clinical acute lung injury. Am J Med 1991; 91 (Suppl. 3C): 54-59.

4. Winsel K. Antioxidative und entzundungshemmende Eigenschaften von Ambroxol. Pneumologie 1992; 46: 461-475.

5. Nowak D, Pietras T, Antczak A, Krol M, Piasecka G. Ambroxol inhibits endotoxin-induced lipid peroxidation in mice. Pol J Pharmacol 1993; 45: 317-322.

6. Nowak D, Antczak A, Krol M, Bialasiewicz P, Pietras T. Antioxidant properties of ambroxol. Free Rad Biol Med 1994; 16: 517-522.

7. Nowak D, Antczak A, Pietras T, Bialasiewicz P, Krol M. Protective effect of ambroxol against heat- and hydrogen peroxide-induced damage to lung lipids in mice. Eur Respir J 1994; 7: 1629-1634.

8. Stockley RA, Shaw J, Burnett D. Effect of ambroxol on neutrophil chemotaxis in vitro. Agents Action 1988; 24 : 292-296.

9. Rozniecki J, Nowak D. Ambroxol inhibits spontaneous migration of human neutrophils. Clin Exp Allergol 1990; 20 (Suppl. 1): 27.

10. Winsel K, Becher G. Effect of ambroxol on chemiluminescence of phagocytic cells and Na-arachidonateinduced bronchoconstriction in guinea-pigs. Eur Respir $J$ 1992; 5 (Suppl. 15): 289s.

11. Bianchi M, Mantovani A, Erroi A, Dinarello CA, Ghezzi P. Ambroxol inhibits interleukin-1 and tumor necrosis factor production in human mononuclear cells. Agents Action 1990; 31: 275-279.

12. Luisetti M, Peona V, Salmona M, et al. Ambroxol and pulmonary toxicity induced by antineoplastic drugs. Int J Clin Pharmacol Res 1986; 6: 129-136.

13. Donnini M, Luisetti M, Diomede L, et al. Ambroxol reduces paraquat toxicity in the rat. In: Wichert $\mathrm{P}$, von Muller B, eds. Basic Research on Lung Surfactant. Progress in Respiratory Research. Basel, Karger, 1990, pp. 329-332.

14. Perry WF, Boyd EM. A method for stdying expectorant action in animals by direct measurement of output of respiratory tract. J Pharmacol Exp Ther 1941; 73: 65-77.

15. Boyd EM. Respiratory Tract Fluid. Illinois, USA, C.C. Thomas Publisher, 1972.

16. Kase Y, Yakushiji T, Seo H, et al. Pharmacological studies on expectorants. Folia Pharmacol Japon 1977; 73: 605-624.

17. Kase Y, Seo H, Oyama Y, et al. A new method for evaluating mucolytic expectorant activity and its application II. Application to two proteolytic enzymes, serratiopeptidase and seaprose. Arzneim Forsch/Drug Res 1982; 32: 374-378.

18. Miyata T, Kai H, Saito M, et al. Effect of ambroxol on pulmonary surfactant-Analysis of fatty acid composition of phosphatidylcholine in the sputum and normal respiratory tract fluid in rabbits. Folia Pharmacol Japon 1986; 88: 57-64.

19. Miyata T, Kai H, Furusawa K, et al. Secretomotor and mucolytic effects of mabuterol, a novel bronchodilator. Arch Int Pharmacodyn Ther 1987; 288: 147-159.
20. Miyata T, Ishii T, Sugiyama N, et al. Effect of N-acetylneuraminic acid on respiratory tract secretion and inflammation in the bronchitic rabbit. Arch Int Pharmacodyn Ther 1990; 304: 277-289.

21. Oda Y, Isohama Y, Kai H, Okano Y, Takahama K, Miyata T. Increased production and/or secretion of pulmonary surfactant in rats by long term sulfur dioxide exposure. J Pharmacobio Dyn 1989; 12: 726-730.

22. Kai H, Kido T, Hamamura I, et al. Monoclonal antibodies against hamster airway mucins. J Clin Biochem Nutr 1995; 19: 89-95.

23. Kim KC, Rearick JI, Nettesheim P, Jetten AM. Biochemical characterization of mucous glycoproteins synthesized and secreted by hamster tracheal epithelial cells in primary culture. J Biol Chem 1985; 260: 4021-4027.

24. Kim KC, Opaskar-Hincman H, Bhaskar KR. Secretions from primary hamster tracheal surface epithelial cells in culture: mucin-like glycoproteins, proteoglycans, and lipids. Exp Lung Res 1989; 15: 299-314.

25. Kim KC, Wasano K, Niles RM, Schuster JE, Stone PJ, Body JS. Human neutrophil elastase releases cell surface mucins from primary cultures of hamster tracheal epithelial cells. Proc Natl Acad Sci USA 1987; 84; 9304-9308.

26. Kim KC, Brody JS. Use of primary cell culture to study regulation of airway surface epithelial mucus secretion. In: Chantler EN, Ratcliffe NA, eds. Mucus and Related Topics. Cambridge, Company of Biologists Limited, 1989, pp. 231-239.

27. Kim KC, Nassiri J, Brody JS. Mechanisms of airway goblet cell mucin release: studies with cultured tracheal surface epithelial cells. Am J Respir Cell Mol Biol 1989; 1: $137-143$

28. Kim KC, Lee BC. P2 purinoceptor regulation of mucin release by airway goblet cells in primary culture. $\mathrm{Br} \mathrm{J}$ Pharmacol 1991; 103: 1053-1056.

29. Kim KC, Wilson AK, Lee BC. Nucleotides and mucin release from cultured airway epithelial cells. Chest 1992; 101: 68S-69S.

30. Kai H, Yoshitake K, Isohama Y, Hamamura I, Takahama $\mathrm{K}$, Miyata $\mathrm{T}$. Involvement of protein kinase $\mathrm{C}$ in mucus secretion by hamster tracheal epithelial cells in culture. Am J Physiol 1994; 267: L526-L530.

31. Yoshitake K, Isohama Y, Kai H, Takahama K, Miyata T. Substance P stimulates the loss of cell-associated high molecular weight glycoconjugates from cultured hamster tracheal epithelial cells through polymorphonuclear leucocytes activation. Biochem Mol Biol Int 1995; 36: 1009-1016.

32. Yoshitake K, Isohama Y, Kai H, Takahama K, Miyata T. Activated polymorphonuclear leucocytes stimulates the loss of cell-associated high molecular weight glycoconjugates from hamster tracheal epithelial cells in culture. Pharmacol Sci 1995; 1: 475-478.

33. De Sanctis GT, Tomkiewicz RP, Rubin BK, Schurch S, King M. Exogenous surfactant enhances mucociliary clearance in the anaesthetized dog. Eur Respir J 1994; 7: $1616-1621$.

34. Allegra L, Bossi R, Braga PC. Influence of surfactant of mucociliary transport. Eur J Respir Dis 1985; 67: 71-76.

35. Morgenroth K, Bolz J. Morphological features of the interaction between mucus and surfactant on the bronchial mucosa. Respiration 1985; 47: 225-231.

36. Gehr P, Schurch S, Berthiaume Y, Im Hof V, Geiser M. Particle retention in airways by surfactant. $J$ Aerosol Med 1990; 3: 27-43. 
37. Girod S, Galabert C, Pierrot D, et al. Role of phospholipid lining on respiratory mucus clearance by cough. J Appl Physiol 1991; 71: 2262-2266.

38. Rubin BK, Ramirez O, King M. The role of mucus rheology and transport in neonatal respiratory distress syndrome and the effect of surfactant therapy. Chest 1992; 101: 1080-1085.

39. Rubin BK. A superficial view of mucus and the cystic fibrosis defect. Pediatr Pulmonol 1992; 13: 4-5.

40. Mercer RR, Russell ML, Crapo JD. Mucous lining layers in human and rat airways. Am Rev Respir Dis 1992; 145: A355.

41. Schurch S, Gehr P, Im Hof V, Geiser M, Green FHY. Surfactant displaces particles toward the epithelium in airways and alveoli. Respir Physiol 1990; 80: 17-32.

42. Kai H, Saito M, Furusawa K, et al. Protective effect of surface-active phospholipids against the acid-inducing inhibition of the tracheal mucociliary transport. Jpn J Pharmacol 1989; 49: 375-380.

43. Wright JR, Dobbs LG. Regulation of pulmonary surfactant secretion and clearance. Ann Rev Physiol 1991; 53: 395-414.

44. Kai H, Murahara K, Isohama Y, et al. 4-Aminopyridine stimulates phophatidylcholine secretion in primary cultures of rat type II pneumocytes. I Pharm Pharmacol 1996; 48: 53-56.

45. Kai $\mathrm{H}$, Isohama $\mathrm{Y}$, Takaki $\mathrm{K}$, et al. Both $\mathrm{b}_{1^{-}}$and $\mathrm{b}_{2}$ adrenoceptors are involved in mediating phosphatidylcholine secretion in rat type II pneumocyte cultures. Eur J Pharmacol 1992; 212: 101-103.

46. Isohama Y, Matsuo T, Kai H, Takahama K, Miyata T. Changes in $b_{1^{-}}$and $b_{2}$-adrenoceptor mRNA levels in alveolar type II cells during cultivation. Biochem $\mathrm{Mol}$ Biol Int 1995; 36: 561-568.

47. Oda Y, Kai H, Isohama Y, Takahama K, Miyata T. Stimulation of pulmonary surfactant secretion by activating neutrophils in rat type II pneumocytes culture. Life Sci 1991; 49: 803-811.

48. Okumura M, Tsuruoka M, Isohama Y, Kai H, Takahama K, Miyata T. Activated eosinophils stimulate phosphatidylcholine secretion in primary culture of rat type II pneumocytes. Biochem Mol Biol Int 1996; 38: 571-577.

49. Wanner A. Clinical aspects of mucociliary transport. Am Rev Respir Dis 1977; 116: 73-125.

50. Wanner A. Mucus transport in vivo. In: Braga C, Allegra L, eds. Methods in Bronchial Mucology. New York, Raven Press, 1988, pp. 279-289.

51. Kubo S, Kase Y, Miyata Y, Kito G, Uesaka I. Pharmacological studies of 1-(o-Chlorophenyl)-2-tert.-butylaminoethanol (C-78), a new bronchodilator. Arzneim Forsch /Drug Res 1975; 25: 1028-1037.

52. Miyata T, Takahama K, Hasanat A, et al. Action of 4amino- $\alpha$-[(tert-butylamino) methyl]-3, 5-dichlorobenzylalchol hydrochloride (N-AB 365, clenbuterol) on the respiratory system. Folia Pharmacol Japon 1978; 74 : 573-588.

53. Inatomi N, Kuriki H, Kanno M, et al. Pharmacological studies of trans-6-hydroxy-5-hydroxymethyl-2-isopropylamino-1,2,3,4-tetrahydro-1-naphthalenol hydrochloride (AA-497), a new potent bronchodilator. Arzneim Forsch/Drug Res 1980; 30: 276-285.

54. Miyata T, Matsumoto N, Yuki H, Takahama K, Okano $\mathrm{Y}$, Kai $\mathrm{H}$. The effect of $\mathrm{N}$-acetylneuraminic acid on the mucociliary transport impaired by cigarette smoke. Arch Int Pharmacodyn Ther 1988; 296: 202-209.

55. Miyata T, Matsumoto N, Yuki H, Oda Y, Takahama K, Kai H. Effects of anticholinergic bronchodilators on mucociliary transport and airway secretion. Jpn J Pharmacol 1989; 51: 11-15.

56. Kai H, Yamamoto S, Takahama K, Miyata T. Influence of corticosterone on tracheal mucociliary transport in pigeons. Jpn J Pharmacol 1990; 52: 496-499.

57. Imai $\mathrm{T}$, Kai $\mathrm{H}$, Isohama $\mathrm{Y}$, et al. Effects of a novel orally-active antiallergic drug, quinotolast (FK021), on airway clearance. Folia Pharmacol Jpn 1994; 104: 347355.

58. Tai S, Kai H, Isohama Y, Takahama K, Miyata T. Effect of leukotriene $\mathrm{D}_{4}$ on tracheal mucociliary transport velocity in quails. Jpn J Pharmacol 1996; 70: 195-197.

59. Miyamoto K, Furusawa K, Kuroiwa A, Saito M, Miyata T, Furukawa T. Effects of Qing-Fei-Tang on the airway inflammation and clearance. Am J Chin Med 1990; 18: $5-18$.

60. Schauer R. Chemistry, metabolism, and biological functions of sialic acids. Carbohydr Chem Biochem 1982; 40: 131-234.

61. Kai H, Makise K, Matsumoto S, et al. The influence of neuraminidase treatment on tracheal smooth muscle contraction. Eur J Pharmacol 1992; 220: 181-185.

62. Sugiyama N, Saito K, Itoh M, Miyata T. Distribution of free N-acetylneuraminic acid in rat organs. Life Sci 1989; 44: 1247-1250.

63. Miyata T, Ishii T, Nishi N, et al. Possible contribution of $\mathrm{N}$-acetylneuraminic acid in the airway defense system. Proceedings of the Kagoshima International Symposium on Glycoconjugates in Medicine. Kagoshima, Japan, Professional Postgraduate Sciences 1987; pp. 183-189.

64. Kai H, Murata Y, Ishii T, et al. Anti-allergic effect of $\mathrm{N}$-acetylneuraminic acid in guinea-pigs. J Pharm Pharmacol 1990; 42: 773-777.

65. Nagaoka S, Tsubura E, Takizawa T, et al. Early phase II clinical study of KI-111. J Clin Ther Med 1987; 3: 923-948.

66. Ito $\mathrm{K}$, Ando $\mathrm{M}$, Araki $\mathrm{S}$, Ishii $\mathrm{T}$, Kai $\mathrm{H}$, Miyata $\mathrm{T}$. Clinical effects of KI-111 (sodium N-acetylneuraminate) on chronic respiratory disease patients administered by inhalation. Ther Res 1989; 10: 683-691.

67. Adcock IM, Brown CR, Gelder CM, Shirasaki H, Peters MJ, Barnes PJ. Effects of glucocorticoids on transcription factor activation in human peripheral blood mononuclear cells. Am J Physiol 1995; 268 (Cell Physiol 37): C331-C338.

68. Beato M, Herrlich P, Schutz G. Steroid hormone receptors: many actors in search of a plot. Cell 1995; 83: 851-857.

69. Marom Z, Shelhamer J, Alling D, Laliner M. The effect of corticosteroids on mucus glycoprotein secretion from human airways in vitro. Am Rev Respir Dis 1984; 129: 62-65.

70. Lundgren JD, Hirata F, Marom Z, et al. Dexamethasone inhibits respiratory glycoconjugate secretion from feline airways in vitro by the induction of lipocortin (lipomodulin) synthesis. Am Rev Respir Dis 1988; 137: 353-357.

71. Shimura S, Sasaki T, Ikeda K, Yamauchi K, Sasaki H, Takishima T. Direct inhibitory action of glucocorticoid on glycoconjugate secretion from airway submucosal glands. Am Rev Respir Dis 1990; 141: 1044-1049.

72. Satoh M, Shimura S, Sasaki H, Ebina M, Takishima T. Dexamethasone modulation of ion-transport and fluid movement across airway epithelium. Am J Physiol 1993; 264 (Lung Cell Mol Physiol 8): L376-L381.

73. Kai H, Yoshitake K, Hisatsune A, et al. Dexamethasone suppresses mucus production and MUC-2 and MUCSAC gene expression by NCl-H292 cells. Am J Physiol 1996; 271: (Lung Cell Mol Physiol 15): L484-L488. 
74. Aubert J-P, Porchet N, Crepin M, et al. Evidence for different human tracheobronchial mucin peptides deduced from nucleotide cDNA sequences. Am J Respir Cell Mol Biol 1991; 5: 178-185.

75. Bobek LA, Tsai H, Biesbrock AR, Levine MH. Molecular cloning, sequence, and specificity of expression of the gene encoding the low molecular weight human salivary mucin (MUC7). J Biol Chem 1993; 268: 20563-20569.

76. Gendler SJ, Lancaster CA, Taylor-Papadimitriou J, et al. Molecular cloning and expression of human tumorassociated polymorphic epithelial mucin. J Biol Chem 1990; 265: 15286-15293.

77. Gum JR, Byrd JC, Hicks JW, Toribara NW, Lamport DTA, Kim YS. Molecular cloning of human intestinal mucin cDNAs. J Biol Chem 1989; 264: 6480-6487.

78. Gum JR, Hicks JW, Swallow DM, et al. Molecular cloning of cDNAs derived from a novel human intestinal mucin gene. Biochem Biophys Res Commun 1990; 171: 407-415.

79. Gum JR Jr, Hicks JW, Toribara NW, Rothe E-M, Lagace RE, Kim YS. The human MUC2 intestinal mucin has cysteine-rich subdomains located both upstream and downstream of its central repetitive region. J Biol Chem 1992; 267: 21375-21383.

80. Gum JR Jr, Hicks JW, Toribara NW, Siddiki B, Kim YS. Molecular cloning of human intestinal mucin (MUC2) cDNA. J Biol Chem 1994; 269: 2440-2446.

81. Lan MS, Batra SK, Qi W-N, Metzgar RS, Hollingsworth MA. Cloning and sequencing of a human pancreatic tumor mucin cDNA. J Biol Chem 1990; 265: 15294 15299.

82. Meerzaman D, Charles P, Daskal E, Polymeropoulos MH, Martin BM, Rose MC. Cloning and analysis of cDNA encoding a major airway glycoprotein, human tracheobronchial mucin (MUC5). J Biol Chem 1994; 269: 12932-12939.

83. Porchet N, Van Cong N, Dufossse J, et al. Molecular cloning and chromosomal localization of a novel human tracheo-bronchial mucin cDNA containing tandemly repeated sequences of 48 base pairs. Biochem Biophys Res Commun 1991; 171: 407-415.

84. Toribara NW, Gum JJR, Culhane PJ, et al. MUC-2 human small intestinal mucin gene structure. J Clin Invest 1991; 88: 1005-1013.

85. Toribara NW, Roberton AM, Ho SB, et al. Human gastric mucin. J Biol Chem 1993; 268: 5879-5885.
86. Shankar V, Gilmore MS, Elkins RC, Sachdev GP. A novel human airway mucin cDNA encodes a protein with unique tandem-repeat organization. Biochem J 1994; 300: 295-298.

87. Gerard CR, Eddy L, Shows TB. The core polypeptide of cystic fibrosis tracheal mucin contains a tandem repeat structure: evidence for a common mucin in airway and gastrointestinal tissue. J Clin Invest 1990; 86: 1921-1927.

88. Gum JR Jr. Mucin genes and the proteins they encode: structure, diversity, and regulation. Am J Respir Cell Mol Biol 1992; 7: 557-564.

89. Jany BH, Gallup MW, Yan PS, Gum JR, Kim YS, Basbaum CB. Human bronchus and intestine express the same mucin gene. J Clin Invest 1991; 87: 77-82.

90. Rose MC. Mucins: structure, function, and role in pulmonary disease. Am J Physiol 1992; 263 (Lung Cell Mol Physiol 6): L413-L429.

91. Miyamoto K, Kuroiwa H, Okada H, Furukawa T. Study of Qing-Fei-Tang. Jpn J Oriental Med 1987; 38: 25-30.

92. Fuchikami J, Takahama K, Kai H, Miyata T. Comparative study of the antitussive activity of Mai-Meu-Dong-Tang and codeine in normal and bronchitic guinea-pigs. Pharmacodyn Ther (Life Sci Adv) 1990; 9: 37-43.

93. Takahashi K, Mizuno H, Ohno H, et al. Pharmacological profile on the new mucoactive agent SS320A, a cysteine derivative. Am J Respir Crit Care Med 1995; 151: A384.

94. De Giovanni L, Fregnan GB, Rabitti C, et al. Lack of gastric adverse effects of erdosteine in rats and men. Int J Clin Pharmacol Ther Toxicol 1991; 29: 269-273.

95. Hosoe H, Kaise T, Ohmori K, Kai H, Takahama K, Miyata T. Pharmacological effects of KW-9144, a new cysteine derivative. Jpn J Pharmacol 1993; 61: 81P.

96. Braga PC, Allegra L, Rampoldi C, Ornaghi A, Beghi G. Long-lasting effect on rheology and clearance of bronchial mucus after short-term administration of high doses of carbocysteine-lysine to patients with chronic bronchitis. Respiration 1990; 57: 353-358.

97. Colombo B, Turconi P, Daffonchio L, Fedele G, Omini C, Cremaschi D. Stimulation of $\mathrm{Cl}^{-}$secretion by the mucoactive drug S-carboxymethylcysteine-lysine salt in the isolated rabbit trachea. Eur Respir J 1994; 7: 1622-1628.

98. Tomkiewicz RP, App EM, Coffiner M, Fossion J, Maes $\mathrm{P}$, King M. Mucolytic treatment with N-acetylcysteine L-lysinate metered dose inhaler in dogs: airway epithelial function changes. Eur Respir J 1994; 7: 81-87. 